\title{
EFEKTIVITAS APLIKASI QUIZIZZ TERHADAP KEMAMPUAN METAKOGNISI MAHASISWA UPBJJ UT-MAJENE PADA MATA KULIAH PENDIDIKAN KEWARGANEGARAAN
}

\author{
Abdul Latif \\ Universitas Terbuka \\ Email: abdul_latif@ecampus.ut.ac.id
}

\begin{abstract}
21 st century learning in the classroom is characterized by the use of ICT, collaboration, communication, and critical and creative thinking. To optimize the learning, it is necessary to optimize the metacognitive ability of students. This research is a quasi-experimental study by treating the application of the quizizz application to UPBJJ UT-Majene students, majoring in PGSD who programmed citizenship education courses. The research resulted in learning tools, namely Quizizz and RAT$S A T$. The data collection tools used are performance tests, observation sheets, and student response questionnaires to the application of quizzz on metacognitive abilities. The data analysis used is descriptive statistical analysis and inferential statistics. The results showed that the quizizz application was effective on the metacognitive abilities of UPBJJ UT-Majene students, majoring in PGSD in civic education courses.
\end{abstract}

Keywords: metacognition, student, quizizz

\section{PENDAHULUAN}

Dalam rangka menghasilkan generasi hebat diera revolusi industri 4.0, maka pembelajaran abad 21 sudah sebaiknya diterapkan, sebab pembelajaran yang diterapkan untuk mengembangkan kemampuan belajar dan literasi. Hal ini menjadi perhatian serius dikalangan para dosen. Permenristekdikti nomor 44 tahun 2015 Bab 1 Pasal 1 mengamanatkan bahwa dosen adalah pendidik profesional dan ilmuwan dengan tugas utama mentransformasikan, mengembangkan, dan menyebarluaskan ilmu pengetahuan, teknologi melalui pendidikan, penelitian, dan pengabdian kepada masyarakat. Berdasarkan hal tersebut maka pembelajaran dikelas seyogyanya menggunakan teknologi. Selain hal tersebut era industri 4.0 yang menjadi tantangan perguruan tinggi terkait paradigma pembelajaran harus mampu diselaraskan, maka dari itu dibutuhkan inovasi dan kreativitas dosen untuk memanfaatkan teknologi dalam proses 
pembelajaran. Tetapi kenyataan dilapangan, dosen masih nyaman dengan cara mengajar yang konvensional, padahal banyak pilihan pembelajaran berbasis digital yang dapat digunakan oleh dosen.

Metakognisi berhubungan dengan kesadaran peserta didik untuk membangun strategi dalam memahami dan memecahkan masalah dalam pembelajaran. Olehnya itu dosen dalam menerapkan pembelajaran harus mampu merubah paradigma pembelajaran menuju pembelajaran abad 21. Osman dan Hannafin (Latif et al., 2019) menggunakan dua kriteria, yakni: pendekatan pelatihan dan hubunannya dengan materi pelajaran Berdasarkan hubungannya dengan materi kuliah, maka strategi yang digunakan disesuaikan dengan karakteristik materi.

Mengenai strategi dosen untuk meningkatkan kemampuan metakognisi mahasiswa, mengemukakan beberapa contoh sebagai berikut (Arsyad, 2016) yakni mahasiswa melalui kesadaran mandiri memonitor cara belajar sendiri, menggunakan starategi SQ3R dan SQ4R, membuat prediksi materi yang akan dibahas berdasarkan modul yang telah dibaca, menghubungkan ide-ide untuk membentuk struktur pengetahuan, mempersiapkan pertanyaan, menyiapkan strategi kapan bertanya dan mentransfer pengetahuan, sikap, nilai dan keterampilan pada situasi atau tugas lain.

Salah satu media pembelajaran digital yang dapat digunakan oleh dosen dan mahasiswa yaitu media pembelajaran berbasis aplikasi contohnya quizizz. Sebagai media pembelajaran e-learning, quizizz dapat digunakan sebagai salah satu instrument asessment pembelajaran. Sehingga dapat menumbuhkan kemampuan metakognisi mahasiswa dalam belajar. Kelebihan quizizz dibanding aplikasi lainnya adalah quizizz mencantumkan dua mode aplikasi yang berbeda. Salah satunya adalah membentuk evaluasi formatif secara real-time di dalam kelas, dan yang lainnya disusun oleh guru kepada siswa sebagai tugas ekstrakurikuler (Orhan \& Gürsoy, 2019).

Berdasarkan kemudahan dalam menggunakan aplikasi quizizz, maka dapat dikatakan teknologi pendidikan juga dapat dipandang sebagai teknik gamifikasi yaitu menggunakan cara pembuatan game ke dalam area belajar dan mengajar. Hal ini sejalan dengan penelitian yang telah dilakukan oleh beberapa peneliti, penemuannya tentang bagaimana teknik gamifikasi dapat meningkatkan motivasi dan keterlibatan siswa di dalam kelas. Berikut adalah gambar 1 tampilan aplikasi quizizz. 


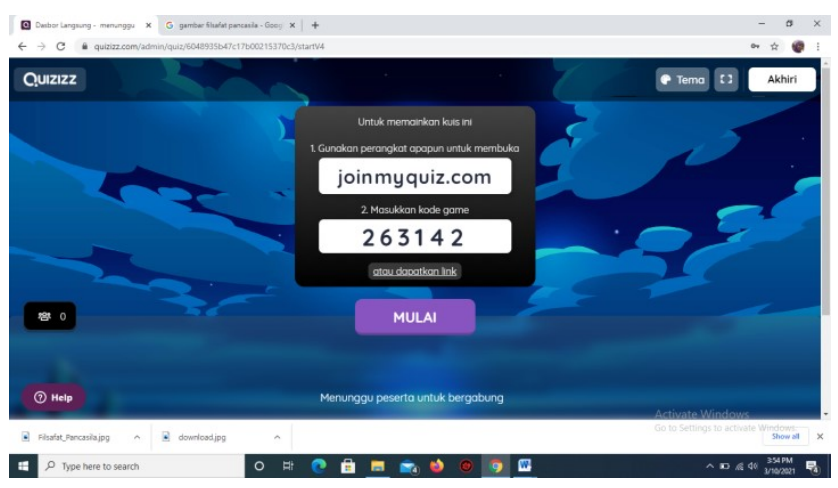

Gambar 1. Aplikasi quizizz

Hasil penelitian pada kampus Politeknik Muadzam Shah Pahang di Malaysia, mahasiswa yang mengikuti mata kuliah desain database dibagi menjadi dua kelompok, dimana satu kelompok menggunakan quizizz sepanjang semester, kelompok lain hanya menggunakan pada acara tertentu. Pengamatan akhir dari penelitian ini mengungkapkan bahwa mahasiswa yang menggunakan quizizz selama semester lebih terlibat dan termotivasi daripada kelompok mahasiswa yang hanya menggunakan sesekali (Ab Rahman et al., 2018).

Penelitian lainnya yang dilakukan oleh (Teng, 2020), (Ahmad, dkk, 2018) dan (Magana et al., 2019) pada dasarnya menemukan bahwa pentingnya meningkatkan keterampilan pengaturan metakognitif pada peserta didik, karena dapat mempengaruhi prestasi belajar peserta didik. Sejalan dengan penelitian sebelumnya oleh (Aşık \& Erktin, 2019) dan (Stanton et al., 2019) konteks pembelajaran dapat mempengaruhi metakognisi peserta didik, dilain sisi penelitian terkait penggunaan quizizz yang dilakukan oleh Purba (2019) yang menyatakan bahwa pemanfaatan evaluasi pembelajaran aplikasi quizizz mampu meningkatkan konsentrasi belajar mahasiswa yaitu sebesar 0,45 dengan kategori sedang.

Hasil observasi awal terhadap dosen pengampuh mata kuliah pendidikan kewarganegaraan, diperoleh bahwa dalam pembelajaran belum pernah menggunakan aplikasi quizizz dalam mengevaluasi pembelaajran. Sedangkan data kemampuan metakognisi mahasiswa program studi matematika yang memprogramkan mata kuliah pendidikan kewarganegaraan masih berada dibawah rata-rata yaitu $57,55 \%$ belum mencapai nilai minimal yaitu $70 \%$. Berdasarkan hasil observasi dan penelitian sebelumnya, maka peneliti tertarik untuk meneliti efektivitas penggunaan aplikasi quizizz terhadap kemampuan metakognisi mahasiswa UPBJJ UT-Majene Kelas Pendas masa registrasi 2020.2 yang memprogramkan mata kuliah pendidikan kewarganegaraan. 


\section{METODE PENELITIAN}

Penelitian ini merupakan penelitian eksperimen semu (quasi experimental) yang melibatkan kelas kontrol dan kelas eksperimen. Desain penelitian eksperimen semu mengacu pada nonquivalent control group desgn (Sugiyono, 2013). Secara jelas disajikan bagan alir penelitian.

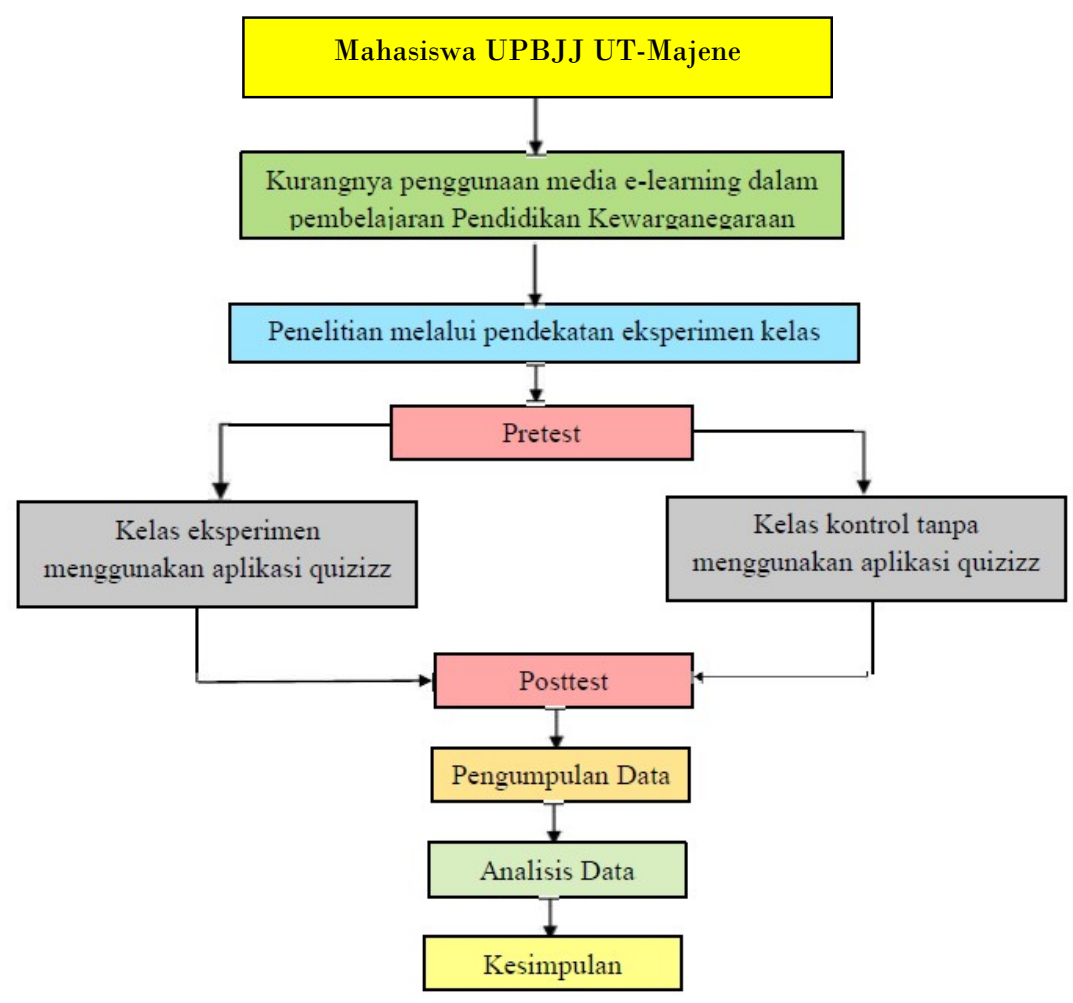

Gambar 2. Bagan alir penelitian

Populasi dalam penelitian ini adalah seluruh mahasiswa UPBJJ UTMajene Jurusan PGSD yang memprogramkan mata kuliah pendidikan kewarganegaraan ditahun akademik 2020-2021. Pengambilan sampel dalam penelitian ini menggunakan teknik random sampling, yaitu penentuan sampel dengan cara acak.

Variable dalam penelitian ini diantaranya:

1. Kemampuan metakognisi

Kemampuan metakognisi mahasiswa mengacu pada indikator, diantaranya: (1) mahasiswa merencanakan tujuan dan faktor pendukung dalam belajar dalam hal ini penentuan lokasi untuk belajar online, (2) strategi 
yang digunakan mahasiswa pada saat mengerjakan tugas secara online melalui aplikasi quizizz, (3) mahasiswa melakukan pemantauan, klarifikasi dan ketepatan dalam memilih jawaban soal, (4) evaluasi ketercapaian tujuan belajar, efektivitas strategi yang digunakan menanggulangi berbagai kesulitan ketika menggunakan quizizz.

2. Aktivitas mahasiswa

Proses pembelajaran dikatakan efektiv bila mahasiswa secara aktif ikut terlibat pada setiap pertemuan proses belajar mengajar yang dilakukan dikelas baik itu menggunakan aplikasi quizizz maupun yang tidak menggunakan, sehingga mahasiswa tidak hanya menerima secara pasif pengetahuan yang diberrikan oleh dosen.

3. Keterlaksanaan dosen

Proses pembelajaran dikatakan efektiv bila dosen melakukan pembelajaran sesuai Rancangan Aktivitas Tutorial - Satuan Aktivitas Tutorial (RAT-SAT).

4. Respon mahasiswa

Proses pembelajaran dikatakan efektiv bila mahasiswa merespon secara positif penerapan pembelajaran.

Instrument dalam penelitian ini, diantaranya: (1) Tes terdiri dari pretest dan postest, (2) lembar pengamatan aktivitas mahasiswa, (3) lembar pengamatan keterlaksanaan dosen, dan (4) angket respon mahasiswa.

Data kemampuan metakognisi mahasiswa diperoleh dari tes yang diberikan kepada mahasiswa, baik sebelum perlakuan (pretest) maupun setelah perlakuan (postest). Data aktivitas mahasiswa diperoleh dengan cara observer mengamati aktivitas mahasiswa pada proses pembelajaran berlangsung. Data keterlaksanaan dosen diperoleh dengan cara observer melakukan pengamatan terhadap kegiatan dosen selama proses pembelajaran utnuk disesuaikan dengan RPS. Data respon mahasiswa diperoleh dengan cara membagikan angket kepada mahasiswa setelah proses pemberian tindakan atau perlakuan dalam penelitian.

Teknik analsiis data terdiri dari dua yaitu statistika deskriptif dan statistika inferensial. Teknik statistika deskriptif digunakan untuk menganalisis data kemampuan metakognisi mahasiswa kelompok control dan kelompok eksperimen, menganalisis data aktivitas mahasiswa, respon mahasiswa serta keterlaksanaan dosen dalam menerapkan pembelajaran.

Sedangkan teknik statistika inferensial untuk menjawab hipotesis penelitian yaitu bagaimanakah efektivitas aplikasi quizizz terhadap kemampuan metakognisi mahasiswa UPBJJ UT-Majene Jurusan PGSD?. Untuk melakukan uji hipotesis, syarat yang harus dipenuhi yaitu uji normalitas dan uji homogenitas.

Pengujian hipotesis statistik dengan menggunakan uji-t. Rumus hipotesis statistiknya, yaitu : 
$H_{0}: \mu_{1}<\mu_{2}$

\section{$H_{1}: \mu_{1} \geq \mu_{2}$}

Keterangan :

$H_{0}=$ nilai rata-rata kemampuan metakognisi mahasiswa yang tidak menggunakan aplikasi quizizz lebih rendah dari nilai rata-rata kemampuan metakognisi mahasiswa yang menggunakan aplikasi quizizz.

$H_{0}=$ nilai rata-rata kemampuan metakognisi mahasiswa yang tidak menggunakan aplikasi quizizz lebih rendah dari nilai rata-rata kemampuan metakognisi mahasiswa yang menggunakan aplikasi quizizz.

\section{HASIL DAN PEMBAHASAN}

Penelitian ini dilaksanakan selama 6 kali pertemuan. Pertemuan pertama dilakukan pretes, pertemuan ke dua sampai dnegan pertemuan ke lima dilakukan uji coba terhadapa penggunaan aplikasi quizizz pada kelas eksperimen, pertemuan ke enam dilakukan postes. Analisis kemampuan metakognisi mahasiswa, disajikan pada tabel 1 berikut.

Tabel 1. analisis kelas eksperimen dan kelas kontrol

\begin{tabular}{|l|l|l|l|l|}
\hline \multirow{2}{*}{ Statistik } & \multicolumn{3}{|l|}{ Kelas Eksperimen } & \multicolumn{2}{l|}{ Kelas Kontrol } \\
\cline { 2 - 5 } & Nilai Pretes & Nilai Posttes & Nilai Pretes & Nilai Posttes \\
\hline Mean & 63 & 73 & 56 & 64 \\
\hline Median & 65 & 67,5 & 50 & 60 \\
\hline $\begin{array}{l}\text { Standard } \\
\text { deviation }\end{array}$ & 6,77 & 10,26 & 9,40 & 8,09 \\
\hline Maximum value & 70 & 95 & 70 & 80 \\
\hline Minimum value & 50 & 64 & 50 & 60 \\
\hline
\end{tabular}

Berdasarkan tabel 1 disimpulkan kemampuan metakognitisi kelas eksprimen berada pada kategori tinggi sedangkan kelas eksperimen berada pada kategori sedang, temuan ini sejalan dengan penelitian sebelumnya yang dilakukan oleh (Latif et al., 2019), (Orhan \& Gürsoy, 2019), (Teng, 2020) dan (Magana et al., 2019) yang menyatakan bahwa pembelajaran menggunakan aplikasi quizizz meningkatkan prestasi belajar siswa.

Data respon mahasiswa terhadap pembelajaran PKn dengan menggunakan aplikasi quizizz berada pada kategori sangat positif yaitu sebesar 90,00\%. Sedangkan data aktivitas mahasiswa diperoleh analsisi setiap aspek, diantaranya: 
(1) mahasiswa hadir dengan menggunakan Microsoft Teams rata-rata $100 \%$, (2) mahasiswa yang mengerjakan kuis pada aplikasi quizizz rata-rata $100 \%$, (3) mahasiswa yang aktif mendengarkan penjelasan dosen rata-rata $85 \%$, (4) mahasiswa yang aktif memberi respon terhadap pertanyaan dosen rata-rata $80 \%$. Berdasarkan hal tersebut disimpulkan aktivitas mahasiswa berada pada kategori sangat aktif.

Data pengamatan terhadap pengelolaan dosen dalam menerapkan pembelajaran menggunakan quizizz terkelola dengan sangat baik, hal ini berdasarkan hasil analysis 100\% aktivitas dosen sesuai dengan RAT-SAT yang telah disusun.

Analisis statistika inferensial, digunakan untuk menjawab hipotesis penelitian aplikasi quizizz terhadap kemampuan metakognisi mahasiswa UPBJJ UT-Majene Jurusan PGSD.

Tabel 2. Analisis uji normalitas data pretes dan postes

\begin{tabular}{|c|c|c|c|c|c|c|c|}
\hline \multirow[b]{3}{*}{$\begin{array}{l}\text { Kelas } \\
\text { Eksperi } \\
\text { men }\end{array}$} & \multicolumn{3}{|c|}{ Kolmogorov-Smirnova } & \multirow[t]{2}{*}{ Postes } & \multicolumn{3}{|c|}{ Kolmogorov-Smirnova } \\
\hline & Statistic & Df & Sig. & & Statistic & Df & Sig. \\
\hline & 0,173 & 20 & 0,162 & Kelas A & 0,145 & 20 & $0,200^{*}$ \\
\hline $\begin{array}{l}\text { Kelas } \\
\text { Kontrol }\end{array}$ & 0,166 & 20 & 0,118 & Kelas B & 0,157 & 20 & 0,166 \\
\hline
\end{tabular}

Berdasarkan tabel 2 terhadap data pretes dan postes kelas ekperimen dan kelas kontrol menunjukkan nilai sig. $>0,05$ yang berarti uji normalitas data terpenuhi.

Tabel 3. Analisis Homogenitas data pretes dan postes

\begin{tabular}{|l|c|c|c|c|}
\hline & $\begin{array}{c}\text { Levene } \\
\text { Statistic }\end{array}$ & df1 & df2 & Sig. \\
\hline $\begin{array}{l}\text { Data pretes } \\
\text { Based on Mean }\end{array}$ & 0,178 & 1 & 38 & 0,675 \\
\hline $\begin{array}{l}\text { Data postes } \\
\text { Based on Mean }\end{array}$ & 2,150 & 1 & 38 & 0,151 \\
\hline
\end{tabular}

Berdasarkan tabel 3 terhadap data pretes dan postes kelas ekperimen dan kelas kontrol menunjukkan nilai sig. $>0,05$ yang berarti uji homogenitas data terpenuhi.

Sesuai dengan syarat pengujian hipotesis telah diperoleh hasil uji normalitas dan uji homogenitas, sehingga pengujian hipotesis dilakukan dengan menggunakan uji t. Berikut hasil analisis uji t. 
Tabel 4. Analisis uji t

\begin{tabular}{|c|c|c|c|c|c|c|}
\hline \multirow[t]{3}{*}{ Nilai } & & & & & & \\
\hline & \multirow[t]{2}{*}{$\mathrm{t}$} & \multirow[t]{2}{*}{$\mathrm{df}$} & \multirow[t]{2}{*}{$\begin{array}{l}\text { Sig. }(2- \\
\text { tailed) }\end{array}$} & \multirow[t]{2}{*}{$\begin{array}{l}\text { Mean } \\
\text { Difference }\end{array}$} & \multicolumn{2}{|c|}{$\begin{array}{l}95 \% \quad \text { Confidence } \\
\text { Interval of Difference }\end{array}$} \\
\hline & & & & & Lower & Upper \\
\hline & 2,98 & 36,04 & 0,005 & 8,70 & 2,77 & 14,63 \\
\hline
\end{tabular}

Berdasarkan tabel 4 diperoleh nilai sig. $<\alpha(0,005<0,05)$ maka dapat disimpulkan penggunaan aplikasi quizizz efektif terhadap kemampuan metakognisi mahasiswa UPBJJ UT-Majene pada mata kuliah pendidikan kewarganegaraan.

\section{SIMPULAN}

Hasil penelitian diperoleh aplikasi quizizz efektif terhadap kemampuan metakognisi mahasiswa UPBJJ UT-Majene jurusan PGSD pada mata kuliah pendidikan kewarganegaraan. Hal ini diprkuat dengan data hasil belaajr mahasiswa kelas eksperimen lebih tinggi disbanding hasil belajar mahasiswa kelas kontrol. Data aktivitas belajar mahasiswa kelas eksperimen lebih aktif dari pada kelas kontrol. Respon mahasiswa terhadap pembelajaran menggunakan quizizz sangat positif. Keterlaksanaan dosen dalam mengelola pembelajaran terlaksana $100 \%$ dan sesuai dengan RAT-SAT.

\section{SARAN DAN REKOMENDASI}

Peneliti lainnya dapat menggunakan aplikasi quizizz pada mata kuliah lainnya, karena penelitian ini hanya di fokuskan pada mata kuliah pendidikan kewarganegaraan.

\section{DAFTAR PUSTAKA}

Ahmad, H., \& Febryanti, F. (2018). Description of student's metacognitive ability in understanding and solving mathematics problem. In IOP Conference Series: Materials Science and Engineering (Vol. 300, No. 1, p. 012048). IOP Publishing.

Aşık, G., \& Erktin, E. (2019). Metacognitive experiences: Mediating the relationship between metacognitive knowledge and problem solving. Egitim ve Bilim, 44(197), 85-103. https://doi.org/10.15390/EB.2019.7199

Latif, A., Yakin, A. Al, \& Ahmad, H. (2019). Digital classroom untuk meningkatkan kemampuan metakognisi. Journal LL_DIKTI IX, 1(1), 7179.

Orhan, D., \& Gürsoy, G. (2019). Computers \& Education Comparing success and engagement in gami fi ed learning experiences via Kahoot and Quizizz. $\begin{array}{llll}\text { Computers } \& \text { Education, } & \text { 135(February), }\end{array}$ https://doi.org/10.1016/j.compedu.2019.02.015 
Rahman, R., Ahmad, S., \& Rabaah Hashim, U. (n.d.). The effectiveness of gamification technique for higher education students engagement in po. International Journal of Educational Technology in Higher Education, 15(41). https://doi.org/10.1186/s41239-018-0123-0

Stanton, J. D., Dye, K. M., \& Johnson, M. (2019). Knowledge of learning makes a difference: a comparison of metacognition in introductory and senior-level biology students. CBE Life Sciences Education, $18(2)$. https://doi.org/10.1187/cbe.18-12-0239

Sugiyono. 2013. Metode Penelitian Pendidikan Pendekatan Kuantitatif, Kualitatif, dan R\&D. Bandung: Alfabeta

Teng, F. (2020). The role of metacognitive knowledge and regulation in mediating university EFL learners' writing performance. Innovation in Language Learning and Teaching, 14(5), 436-450. 